\title{
A Critical Approach to Gender Identities in the "Muxe" Case
}

\author{
Carlos Mendoza-Álvarez ${ }^{1}$, Saúl Espino-Armendáriz ${ }^{2}$ \\ ${ }^{1}$ Department of Religious Studies, Iberoamericana University, Mexico City, Mexico \\ ${ }^{2}$ Center for Historial Studies, El Colegio de México, Mexico City, Mexico
}

Email address:

carlos.mendoza@ibero.mx (C. Mendoza-Álvarez), saulmx@gmail.com (S. Espino-Armendáriz)

To cite this article:

Carlos Mendoza-Álvarez, Saúl Espino-Armendáriz. A Critical Approach to Gender Identities in the "Muxe" Case. Humanities and Social Sciences. Vol. 6, No. 4, 2018, pp. 130-136. doi: 10.11648/j.hss.20180604.16

Received: July 24, 2018; Accepted: August 17, 2018; Published: September 11, 2018

\begin{abstract}
This paper provides an interdisciplinary approach to the Muxe collective, a sexual diverse community rooted in the millenary Zapotecan culture, located in southern Mexico. The muxe subjectivity is portrayed in some interviews, based on the focal life history methodology. As a critical approach to gender issues, this analysis emphasizes the fluidity of the sexual and gender subjectivity of the muxeidad with ethnical, ethical and communitarian dimensions. The social context is considered from the concept of necropower, coined by the African thinker Achille Mbembe. The experiences of violence and oppression in the muxes' lives are analyzed, as well as the tactics and strategies of resistance that they have developed over recent years. Muxes have an extraordinary resilience that translates into bountiful spirituality. The dimensions through which they express their identities, practices and political options are quite symbolic and diverse. The values, beliefs and spiritual practices result inextricably linked to the muxe subjectivity, allowing us to understand that this community is a sign of change of world, as a theological reading in which their resilience may reflect a Messianic anticipation of the Kingdom of God. An analysis of these resistances in the case of some muxe individuals and collectives demonstrates the crucial importance of dismantling the sacrificial religion that justifies the segregation and scapegoating of the muxes. The original wound of being human is transformed here from fragility to resilience, into what can be considered an eschatological anticipation of the messianic temporality. In conclusion, this paper asserts that the muxe collective portrays a glimpse of another kind of intersubjective paradigm.
\end{abstract}

Keywords: Vulnerability, Resiliency, Systemic Violence, Muxes

\section{Introduction: Systemic Violence and Its Various Gender Exclusions}

Nowdays the world is facing a critical moment in the civilization model generated by instrumental Eurocentric rationality stemming from the establishment of technoscientific modernity as a hegemonic practice and discourse. Global warming is the most alarming expression of this depredatory social and economic model. The foundation of this model of civilization lies in neoliberal capitalism that has spread throughout the planet, sustained by the model of an extractionist State that subordinates the life we share in common (res publica) to the dominant economic, political and patriarchal interests of $1 \%$ of the world population. Enlightenment's original ideal of achieving individual autonomy through emancipation from external tutelage was based on a false assumption: the idea that the individual is lord and master of his own destiny, where nature is merely a field for him to possess, where the other is an enemy to be dominated through the action of the State, and God is the main enemy of human freedom.

Although this ideal of the emancipation of humankind was laudable as an aspiration to affirm the human condition, the model prevailing since the Industrial Revolution has been marked by a specific gender assumption pervading all spheres of subjectivity: the patriarchal will to dominate, which associated the male figure with the image of an almighty God ruling the cosmos as lord and master [1]. This image of one-sided thinking found a powerful cultural ally in the monotheistic religions that make invisible all differences, particularly gender diversity. 
The European and Anglo-Saxon feminist discourse from the mid-twentieth century sounded the alarm regarding the predominance of the patriarchal system. Assuming the egalitarian demands of the second-wave feminisms but going even further, new feminist theologies analyzed intersectionally women's oppressions in which non-white, poor and non-binary identities gave way to a new concept that denounced the will to dominate underlying the patriarchal model as kyriarchal power: the power that imposes domination as submission throughout the different gender identities [2].

However, in recent decades, transfeminisms [3] and queer theory [4] have touched a sore spot regarding gender exclusion: the multiplicity of preferences, identities, and subjectivations should be recognized as gender diversity rights, but always linked to the issue of the predominance of the system of structural exclusion that generates systemic victims.

For this reason, in times of globalization of an exclusionbased model of civilization -a model founded on a complex misogynous, homophobic and death-oriented (necrophile) system - the theology of sexual and gender diversity should be open to listening to the experiences, resistances and alternative practices of collectives that posit an inclusive model of intersubjective relationships. It will be necessary to discern the domination drives still surviving in these practices and their corresponding narratives, the intersubjectivity networks that they are able to generate, and, if applicable, the signs of the times that through these new forms of sociality announce the establishment of Civitas Dei in the midst of a civitas terrena.

\section{Method}

Complex phenomena require interdisciplinary approaches. Such is the case with the polyhedral oppression of kyriarchal power, as well as the multiple resistances and resiliencies that arise alongside it. In this research, we focus on the case of the muxes, a sexual-gender diverse collective rooted in the millenary Zapotecan culture located in southern Mexico.

Methodologically, draw upon oral history. Through five interviews held in the Summer of 2016 in Juchitán (Oaxaca) and in Mexico City, we chose to outline the features of the muxeidad (the 'muxeity') using the words of the muxes themselves, with almost no intrusion from the interviewer. In order to achieve so, we followed the focal life history [5] methodology that is frequently used in collective memory studies in Latin America. The flexible conversation was basically divided into four parts. First, we asked the muxes to introduce themselves and to freely describe why and how do they identify as such. Second, throughout the conversations, whenever memories of violence or oppression arose, the interviewer took carefully transcriptions of the words used by the subjects. The third part of the conversations was headed subtly to the relations between the muxes, the women, the men, and the people from the LGBTQ community in urban milieus. Finally, the last part of the conversation consisted upon open questions about their spirituality, their beliefs, practices and religious values. With their previous authorization, we kept their given names in this paper.

\section{Results}

"Sexual diversity ... isn't only black and white, but there is a whole spectrum of colors." Felina, a famous muxe from Juchitán de Zaragoza, Oaxaca spoke these words, which may well be the best description of the alternative gender paradigm representing muxe condition. Contrary to the binary -male/female- gender system in the West, that has even been perpetuated in homosexual relationships under the straight mind so incisively criticized by Monique Wittig [6], the muxeidad, as muxes themselves refer to their collective distinctiveness, represents a holistic and crosscutting paradigm in which the gender dimension with its oppressions and resistances cannot be separated from its ethnic, ritual and ethical dimensions.

Being muxe [7] is not only related to sexual preference or gender identity. Although muxe condition has often been studied from an anthropological perspective as part of the third sex phenomenon [8], according to the testimonies collected, it goes beyond the field of sexuality. Within this field, polysemy and malleability stand out, since far from accommodating to any of the Western sex-gender categories: transvestite, queen, transsexual, transgender, homosexual, gay, and so on, it goes beyond them using another type of classifications. "Here in Mexico City," says Mariana -a muxe who has been living in the capital city for 15 years- "we go by different names." However, none of them manages to explain the muxe condition. Although there is a division between "feminine" and "masculine" muxes, depending on the clothing they wear, many of them when pushed to translate their identity into Western terms, end up taking on one of the letters in the LGBTQ acronym. Within this paradigm, however, it is other divisions that function.

In the first place, the muxe distinctiveness is intimately linked to the ancestral Zapotec culture and its particular gender regime, an order in which, in contrast with Western history, women occupy a different position [9] where role difference, although existing and in fact strongly marked, is defined under another scale of values [10]. Secondly, muxe is also an ethical category. Muxe is a "hard working and honest" person, says Huicho; "respectful, more than anything," says Mariana; "a cool person," says Kika; "he/she is everything... woman, man, hardworking," says Jocelyn... Commitment to the community at a family and collective level is another of the characteristics defining the muxe selfhood. In spite of having experienced abuse, the five muxes interviewed had been able to forgive their parents for the discrimination and violence they had inflicted on them. Today, they support and care for their parents. To be a muxe, says Felina, "implies so many situations; one of which is to not abandon the family." Thirdly, celebratory feasts are a favorable social space for a 
muxe. The testimonies underscored that muxes are linked to feasts not only for entertainment and sociability. They coincided in viewing celebratory feasts as the most important space for muxe sociability. It is not only a space where they can meet and enjoy conviviality, but it is also a space where they work as cooks, hairdressers, clothing designers, and florists. All these jobs depend on ritual feasts like the festivals known as velas [11] and on social celebrations like weddings, fifteen-year-old debutante balls [12] and so on. Needless to say, these two aspects, that is, the bond with the community and the celebratory feasts that mark the community 's economic, social and cultural pace, like the muxe condition itself, are an indissociable component of the Zapotec culture [13].

Historically speaking, the Isthmus of Tehuantepec located in southern Mexico- is a region that has typically been a crossroads of cultures and a place of extensive social mobility. In recent decades, there has been an increase in both the immigration of people from other places - markedly from Central America- and the emigration of native people from the Isthmus to Oaxaca City, Mexico City and the United States. These population displacements have had repercussions on the muxes. Most of the muxes that were interviewed live or lived for several years in the capital city of Mexico. The testimonies reveal that the trans aesthetic and culture is perceived as a novelty that had a determining influence on the configuration of contemporary muxeidad [14]. In light of these experiences in Mexico City, for instance, the interviewed muxes were able to be more critical of the Juchitecan couple relationship models, in which a muxe and his/her partner -a "man" referred to as a mayate [15] who apparently only feels drawn to the femininecannot live together, "like in Mexico City where homosexuals," Felina highlights, "marry because they are equals" [16].

In addition, the climate of violence derived from statelevel government corruption and drug trafficking involving both mafias and authorities, has affected the social dynamics in Juchitán, including those of the muxes. "Now, there is a lot of violence," Mariana regrets, "we no longer have that much freedom [...] one can no longer go out at night." This lack of security, which is widespread, is accompanied by specific violence against the muxes, which is also something new. In the collective memory constructed in the testimonies, violence within the family and discrimination have been ever present. Hate crime, however, has been identified as a painful novelty. In the last ten years, stated Kika, "eight people I know, very close friends of mine (comadres), have been murdered." The three levels of the State -municipal, state and federal- are either complicit with the violence exercised against the muxes or ignore those crimes. Jocelyn, for example, who continues to be a sex worker, narrated how a municipal president "would have all of us removed from the streets." And the local police would demand sexual favors in exchange for their release: "They don't reject us," says Kika, "but they never really help us out" [17].

It is these adverse situations and brutal violence that make the solidarity and support networks among muxes more visible. Traditionally, solidarity networks among muxes came to life when they migrated. For example, Mariana was able to move to Mexico City thanks to her friend Amaranta. Every time she visits Juchitán and "a girl wants to come over here," Mariana offers her accommodation and tries to get her a job. However, with widespread violence and violence specifically targeting muxes, "we now phone each other every day. We see each other. We communicate," Huicho expressed. Jocelyn, for instance, recently organized a street collection to support a muxe "sister sex worker" in Guadalajara "who was physically attacked and is in very bad way." In another case, Felina had to abandon Juchitán because of a death threat made against her, but a comment came up among some of the interviewees: "We encouraged her and she is back with us again. She has our support" [18].

In fact, the contemporary history of the muxes and some of their most recognized institutions -such as Vela de las Auténticas Intrépidas Buscadoras del Peligro ('Vela' of the Authentic Intrepid Danger-Seekers), or civic associations like Las otras hijas de San Vicente (The Other Daughters of San Vicente), and Gunaxhii Guendanabani, which means "Love Life" in Zapotecan- have been characterized by sexual education and STD prevention efforts, mainly addressing HIV-AIDS. In the three interviews in which this issue was approached, it became clear that the muxes had been able to transform a threat that was decimating them, into an opportunity to weave more liberating bonds where, as Jocelyn recalled, "it is known that muxes practice solidarity" and that "a common cause unites us".

Muxes have an extraordinary resilience that translates into bountiful spirituality [19]. The five muxes who were interviewed identify as Catholic and although they do not celebrate the sacraments regularly nor do they express belonging to a specific Catholic community, they do feel a strong devotion to saints like Judas Thaddeus, participate in the liturgical celebrations accompanying the Juchitecan feasts devoted to a certain saint -known as "las velas" - and, in fact, have a good relationship with the priest of the San Vicente Ferrer Church, as part of the local Juchitecan Church. However, within the context of Mexico City, some muxe leaders interpreting the position the Church grants them as peripheral, and, viewing Christianity as a religion that has historically oppressed muxes, opted to secularize all the ritual referents of the muxe "vela" in the capital city and thus retrieve the "ancestral roots" of the Zapotec culture: the saints were replaced by the iguana [20]. These experiences of spiritual resistance and resilience [21] vis-à-vis the hegemonic models of religiosity remain to be analyzed in detail.

Following a pathway that is different from queer theory, the muxe paradigm evidences not only the flexibility, fluidity and instability of gender categories [22], but also the fact that erotic desire is always errant [23]. As Judith Butler states, sex-gender configurations are merely fixed by "a repetition and a ritual, which achieves its effects through its naturalization in the context of a body" [24]. However, 
all this does not imply a critical assumption that Juchitán is the Paradise of diversity and that muxeidad is a perfect model. It is an alternate paradigm in which there exist other oppressions and forms of violence, different from those prevailing in Western hetero-normativity [25]. This was only a first approach to a complex gender regime, which, like Veronika Bennholdt-Thomsen states, although "we wouldn't be able to imitate it", at least we can use it as "imaginative strength to conceive a different social order" [26].

\section{Discussions}

\subsection{Subjectivations as Counterculture}

A half a century ago, Michel Foucault proposed a critical analysis of the idea of the subject, prevailing as the great assumption in modern rationality. It is an abstract Cartesian or Kantian subject, claiming to be universal, but in fact driven by power camouflaged as knowledge and autonomy [27]. Some German philosophers -like Walter Benjamin, Martin Heidegger and Hannah Arendt- raised awareness about the Welfare State devices through which life in common operates in concrete terms [28]. It is no longer a model of the State based on universal law -with the assumed but false claim that it is valid for all human beings- but rather a historic configuration of subjectivation processes that subordinate people and citizens to the logic of the Welfare State. The notion of biopower -proposed by the French philosopher to analyze the historical, economic and political mechanisms through which subjectivation is carried out in modern societies- is thus of great relevance.

After the Shoah, European political, philosophical and theological thinking considered the unthinkable: the banality of evil. Out of this line of thought emerged anamnestic rationality, understood as the dangerous memory, for example, in Johan-Baptist Metz [29] or, according to Gustavo Gutiérrez, as a praxis of liberation, in search of a historical transformation of exclusion based on the praxis of the oppressed [30].

The end of the Cold War unleashed neoliberal capitalism allowing it to expand as the only one hegemonic system with the full burden of abyssal power coming from one-sided thinking, denounced and critically analyzed by Boaventura de Sousa Santos [31].

If this process is seen from the point of view of underside of history, the system's collapse has already been announced. In its death rattle, the system keeps mutating: the androcentric model of civilization -with its neoliberal capitalist and male chauvinist patriarchal expression- has now transmuted into an actual necropower [32]. In fact, the State is now favoring the death of those majorities seen by the market as useless. The idea is to get rid of the "trash population" which is in the way of capital's interest for territories that it considers imperative to possess in order to extract minerals, drinking water, and other natural resources that are to be put on the market for privileged minorities to consume.

Such necropower extracts life not only from territories, but also from bodies that have been made vulnerable. Necropower is thus not only a misogynous power that sacrifices women and uses their bodies as trophies, but it is also homophobic and devastates any transgressive corporality.

In spite of necropower's devastating logic, the sexual resistance of both individuals and collectives with multiple gender identities, preferences and practices, is highly significant to reflect about the change of world is currently happening, a change from the underside of history of domination [33] Transfeminist movements, for instance, together with the practice of new masculinities and the narratives emerging from them, join the complex interweaving of LBGTQ diversity collectives with a specific human rights agenda that includes sexual and reproductive rights, as well as the right to freedom of expression that aims to dismantle the power of abyssal thinking, monotheistic and necrophiliac patriarchal societies.

\subsection{The Intersubjectivity Emerging from Latin American Resistance Movements}

Various initiatives such as the World Social Forum at Porto Alegre, the Earth Chart and The Declaration Toward a Global Ethic are expressive of the critical surveillance emerging from social and spiritual movements since the end of the twentieth century.

Within the field of gender practices and critical thinking, queer theory has taken on relevant nuances in Latin America and the Caribbean that give it validity and pertinence from the perspective of epistemologies of the South. The heart of the matter lies in defending resistance mainstreaming in the face of the all-embracing oppression of violent patriarchy typical of one-sided thinking, extractionist economy and sacrificial religion. Let us explain.

The transfeminism proposed by some gender movements on the Mexico-United States border links gender claims to a critique of necropower [34]. In fact, gender exclusion is not only an issue related to the individual rights of minorities, such as the right to marriage and reproductive health, which are undoubtedly essential for the universal validity of human rights. But today male chauvinistic, patriarchal, and homophobic exclusion are intimately linked to a narco-State system [35] that subjects bodies and territories to trafficking in persons, organs, weapons and drugs. This is accompanied by a symbolic narrative common to necropower, which is characterized by Holy Death worship, Satanic cults and other forms of magical or animistic religiosity. In this context, the transgressive practices experienced by transfeminist collectives are a sign of ethical outrage and an anarchic practice vis-à-vis systemic violence.

Furthermore, abyssal thinking exercises epistemic violence against sexual diversity minorities that its will-to-power mandates should be dismantled. This is a will-to-power that subjects people and territories to the logic of kyriarchal domination. For at least five centuries of Colonial 
domination epistemic violence has made invisible the ancestral knowledge of native peoples with its practices and mechanisms for the inclusion of gender diversity. Such is the paradigmatic case here: the muxe collective as a complex ancestral gender relation practice that aims to be inclusive and which some social actors now see through a decolonizing lens.

The symbolic and ritual dimension through which they express their resistances, identities, practices, preferences, and social and political options is a third element of gender diversity resistance. It will be of relevance here to analyze the post-Christian hallmark of some muxe collectives that have experienced forced mobility from their birthland in Juchitán, Oaxaca. Some have traveled to the urban context of Mexico City and others to cities in the United States, like Los Angeles, Chicago or New York, thereby transforming their identity, as well as the practices, narratives and the symbols with which they express their muxe condition.

\subsection{Messianic Temporality as an Anticipation of Redemption, a Theological Perspective}

Having set forth the issue of the logic of abyssal thinking with its patriarchal and kyriarchal will to dominate, the glimmers of redemption can be seen emerging through the multiple resistances of systemic victims responding to a violent history. It is thanks to the practices of resilience carried out by these victims that change of world is possible. Muxes and their collective resiliences are indeed part the glimmer of hope for humankind as a whole.

In this synthetic moment of reflection, let us look some theological elements for an interpretation that is relevant to the signs in postmodern times pointing to a "Messianic anticipation" of the fullness of the history inaugurated by Jesus of Nazareth.

A postmodern eschatology of the end times can be characterized by at least three different features: (i) the "contraction of time" carried out by the righteous in history; (ii) the potential of vulnerability expressed as ethical, political and mystical outrage; and (iii) the sense of proactive hope that comes from the multiplicity of resistances, like the case of the muxe collective in the context of gender, class and ethnic discrimination.

The first element is the subversion of violent temporality through acts of self-donation by the righteous. Postmodern Latin American theology is here reading the signs of the times through which the Kingdom of God materializes. In the midst of the patriarchal hegemonic system, the LGBTQ minorities -in their multiple resistances, identities and practices of collective and personal affirmation- denounce the current necropower model of the State as complicit with the exclusion to which they are subjected.

Through diverse practices of gender resistance - such as the social and spiritual critique the muxes make of patriarchal and homophobic Christianity- it is possible to dismantle the power of the male chauvinist caste underlying necropower, which dominates societies with a certain complicity of monotheistic religions. This deconstruction of patriarchy's symbolic power makes it possible to include gender, identity and sexual practice diversity, expressive of a diverse human condition.

Lastly, an analysis of these resistances in the case of some muxe individuals and collectives demonstrates the crucial importance of dismantling the sacrificial religion that justifies the segregation and scapegoating of the muxes, as well as other collectives of gender diversity in order to maintain the supposed stability, purity and benevolence of life under a male chauvinist and androcentric culture, characterized by the mayates in the Zapotec context.

The proposal here is to read through a decolonizing lens of the post-Christian ritual practices of myriad gender diverse people and collectives as a critique of sacrificial religion and epistemic violence that has turned the male chauvinist, the mayate and the kyriarchal woman into the prevailing model of domination.

\section{Conclusions}

María Stella Rodríguez, a Colombian theologian, states that resilience can be seen as locus theologicus from which a new reflection can be generated from the victims' perspective [36]. Precisely the issue of the victims' resistance was developed in a recent work titled Deus ineffabilis [37].

So this paper shows that the muxe collective portrays a glimpse of another kind of intersubjective paradigm. The life stories generously shared by Mariana, Jocelyn, Felina, Huicho and Kika bear hints of hope through which resilience becomes indeed a locus for theological reflection. In their transgressive subjectivity, both binary and nonbinary, ancestral and modern -and with a holistic understanding of sexual and gender subjectivity that includes explicitly ethical, ethnical and spiritual dimensions- the muxeity gives us a clue of how to face kyriarchal oppressions creatively.

It is perhaps through returning to the wound typical of the human condition that has been attacked and made vulnerable, which transforms its fragility into a possibility of resilience, that we may actually announce a new model of intersubjectivity and commonly shared life. Beyond market capitalism -with its extractionist State and its dominationoriented patriarchal and sacrificial religion- it is possible to catch a glimpse of the construction of new forms of sociality in resistance, where people in relation to otherness and nonnarcissistic self-affirmation adopt a common horizon of active survival that opens up avenues of hope to all.

\section{Acknowledgements}

*Article translated by Leslie Pascoe.

We thank the Iberoamericana University in Mexico City for the translation granted. We also thank to Héctor Conde Rubio, research assistant from the Department of Religious Studies at Iberoamericana University, for his editorial help. 


\section{References}

[1] It is worth to remember here the classical criticism Mary Daly made to the patriarchal idea of God: "After the Death of God the Father" in Beyond God the Father, Toward a Philosophy of Women's Liberation. Boston, Beacon Press, 1973, p. 13-43.

[2] See Elisabeth Schussler Fiorenza, Wisdom Ways: Introducing Feminist Biblical Interpretation. New York: Orbis Books, 2001.

[3] See Miriam Solá \& Elena Urko (eds.), Transfeminismos. Epistemes, fricciones y flujos. Nafarroa: Editorial Txalaparta, 2014.

[4] See Marcella Althaus-Reid, La teología indecente: perversiones teológicas en sexo, género y política. Barcelona: Bellaterra, 2005.

[5] See Jorge E. Aceves Lozano, "Un enfoque metodológico de las historias de vida" in Graciela de Garay (ed.), Cuéntame tu vida. Historia oral: historias de vida. México, Instituto de Investigaciones Dr. José María Luis Mora, 1997, p. 9-15.

[6] "Masculine/feminine, male/female are the categories which serve to conceal the fact that social differences always belong to an economic, political and ideological order ... For there is no sex. There is but sex that is oppressed and sex that oppresses. It is oppression that creates sex, and not the contrary." Monique Wittig, El pensamiento heterosexual y otros ensayos. Madrid, Barcelona; Editorial Egales, 2006, p. 22. In this same sense, in an interview in 2013 Bourdieu held that the real content of sex "against nature" was to go against the "social hierarchy" and that homosexuals "reproduce the masculine/feminine hierarchy in their couple relationships" when they perpetuate the active/passive binary. See Catherine Portevin and Jean-Philippe Pisanias, "Entrevista a Pierre Bourdieu: la transgresión gay y dominación masculina," in Sociólogos. Blog de actualidad y sociología, available at: http://ssociologos.com/2013/05/12/entrevista-a-pierrebourdieu-la-transgresion-gay-y-dominacion-masculina/, accessed on 06-01-2016.

[7] There are two different theories regarding the etymology of the word muxe. Some consider that it comes from namuxe that in Zapotec means shy or fearful. Others believe it is a Zapotecan rendering of the word mujer, woman in Spanish. See Elí Bartolo Marcial, "Los enseñantes de la diversidad," in Sergio Santamaría and Nallely Tello (eds.) Elí Bartolo. Filósofo de la muxeidad y enseñante de la diversidad. Oaxaca, Consorcio para el Diálogo Parlamentario y la Equidad Oaxaca y Servicios para una Educación Alternativa, AC, 2015, p. 17.

[8] Anthropology has studied the third sex phenomenon in Amerindian cultures under the term berdache or two-spirit. More critical studies on this theme, without denying that it is a gender regime that differs from the Western one, demonstrate that many of these studies are typically exoticizing. For a study of the thirdgender social phenomenon in Amerindian cultures from the perspective of gender performativity, see Michael J., Horswell, "Toward an Andean Theory of Ritual Same-Sex Sexuality and Third-Gender Subjectivity," in Pete Sigal (ed.), Infamous Desire. Male Homosexuality in Colonial Latin America. Chicago: The University of Chicago Press, 2003, p. $27 \mathrm{ff}$.

[9] In explaining the important role women play in the economy and social rituals, it has been claimed that the Zapotec culture is matriarchal or matrifocal. See Veronika Bennholdt-
Thomsen, "Juchitán, la ciudad de las mujeres," Juchitán, la ciudad de las mujeres. Oaxaca: Instituto Oaxaqueño de las Culturas, Fondo Estatal para las Culturas y las Artes, 1997, p. 24-25. More recent anthropologists, like Marinella Miano, Hombre, mujer y 'muxe' en el Istmo de Tehuantepec. Mexico, Conaculta, INAH, Plaza y Valdés Editores, 2002, p. 15, have criticized this vision.

[10] Beverly Chiñas claims that the key lies in the Zapotec culture, which in spite of being strongly segregated by sex, considers that the sexual aspect is of secondary importance in defining a person's value. In other words, there are in fact clearly marked role differences, but they are not hierarchized as in the Western world. See Beverly Chiñas, The Isthmus Zapotecs. Women's Roles in Cultural Context. New York: Holt, Rinehard and Winston, INC, 1973, p. 111.

[11] A vela is a ritual Zapotec feast usually in honor of a Catholic Saint. These celebrations, expressive of popular religiosity, are organized by the mayordomos (communities stewardship) and follow a very clear protocol (the mass, the tossing of fruit, the dance, etc.). Throughout the year there are myriad velas in Juchitán and the Isthmus, but it is in May that the main vela take place, including the Vela of San Vicente Gola known as El Grande, the Great One, Juchitán's patron saint. See Marinella Miano, Hombre, mujer y 'muxe' en el Istmo de Tehuantepec, p. $127 \mathrm{ff}$.

[12] The fifteen-year old debutante ball (XV años) is celebrated in Mexico when girls reach the age of 15 as a way of introducing a young girl to society.

[13] See Brigitte Holzer, "Economía de fiestas, fiestas como economía," in Bennholdt-Thomsen, Juchitán, p. 79-96.

[14] The resilience that allows them to adapt and take ownership of the cultural novelties in their surroundings is one of the qualities anthropologists have highlighted from the Zapotec culture: "Zapotecs absorb and incorporate new elements into their culture without thus weakening it. On the contrary, they nourish and enrich it." See Margarita Dalton, Mujeres, género e identidad en el Istmo de Tehuantepec. Oaxaca: Centro de Investigaciones Superiores en Antropología Social, 2010, p. 157. In fact, scholars like Flores Martos interpret the emergence of the contemporary muxe as a "Zapotecization" of a modern identity "in the context of a cultural resurgence or ethnogenesis, and at the same time they have become visible and taken on importance in the practice of different mestizo performances, such as sociability in social clubs and travestite shows." Juan Antonio Flores Martos, "Cuerpos poderosos y sobrexpuestos: los muxes de Juchitán como transgéneros amerindios modernos," in Pedro Pitarch and Gemma Orobith (eds.), Modernidades indígenas. Madrid: Iberoamericana-Verveurt, 2012, p. 321.

[15] Mayate is a category related to that of chichifo (a male hustler) in other contexts. It refers to a heterosexual man who has sexual relations with other men -in this case with muxesin exchange for money or favors. Not all muxe husbands are mayates, but all of them "far from hiding their sexual activity linked to the muxes, brag about their adventures and intimate encounters in order to construct symbolic prestige so as to thus reproduce the hegemonic model of masculinity" Joaquín Robles Mora, "Introducción" in Santamaría and Tello (eds.), Elí Bartolo. Filósofo de la muxeidad y enseñante de la diversidad, p. 10.

[16] Since 2006, the Legislative Assembly of Mexico City approved domestic partnerships, contemplating the possibility of same-sex marriage. Since then a dozen states have approved this form of marriage. 
[17] Brutal violence is exercised against the LGBTQ population in Mexico and other Latin American countries. This is clearly illustrated by the case of Viviany Beleboni, a transexual model who participated in the LGBTQ pride parade in São Paulo in June of 2015. She was attacked by a man who claimed to "act in the name of God" because the model had appeared seminude, carrying a cross and wearing a crown of thorns like Jesus on the way to Calvary. See André Musskopf, "Cuerpo, gracia y placer para teologías no-sacrificiales" in Carlos Mendoza-Álvarez and Héctor Conde (comp.), Arqueología de la violencia: Nuevos paradigmas en el pensamiento y el lenguaje para la praxis no-violenta. México: Universidad Iberoamericana, 2017, p. 167-178.

[18] It is interesting to see how the LGBTQ population has generated a very specific kind of solidarity. This muxe solidarity can be seen as a practice of resilience carried out by victims of exclusion.

[19] In one of his texts, Elí Bartolo recalls two myths describing the foundation of the muxeidad. Saint Vicente Ferrer is the protagonist in these two myths. In one of them, the Dominican Saint from Valencia, the founding patron of Juchitán and creator of the Isthmus, is carrying a sack of muxes to Central America and Mexico, but it tore and most of them fell in the Isthmus region. The other myth says that, "Saint Vicente preached in his sermons that all men should love another man, Jesus, the son of God, and that all women should love another woman, the Virgin Mary, Mother of God." According to Bartolo, "this idea reinforces the existence and tolerance towards muxe identity from a 'theological' perspective." See Elí Bartolo Marcial, "Los enseñantes de la diversidad," in Santamaría and Tello (eds.) Elí Bartolo. Filósofo de la muxeidad y enseñante de la diversidad, p. 18.

[20] The iguana is not only an animal that represents the Isthmus as well as part of the region's culinary tradition, but it is also a play on words allusive to homosexuality ("the iguana leaps from stick to stick..."). Besides, it has already been seen that contemporary muxeidad is a Zapotecization of modern gender configurations, rather than of systems preceding the Conquest.

[21] By resilience we understand the dynamic process "that allows for positive development to take place, even in contexts of great adversity, based on a set of abilities that make up this complex and changing capacity." See María Stella Rodríguez Arenas, La resiliencia como vivencia del Reino de Dios. Bogotá: Editorial Pontificia Universidad Javeriana, 2015.

[22] See Marta Lamas, "El fenómeno trans", Debate feminista, No. 39, 2009, 11.

[23] Barbosa's thesis, with a clear psychoanalytic background, is that muxe identity not only challenges Western sex-gender categories, but also demonstrates that desire is always ungraspable. See Luanna Barbosa, "Muxes de Juchitán: sobre la errancia y el efeminismo en campo," Seminário Internacional Fazendo Género, No. 10, 2013, p. 4.
[24] This is how Butler defines performativity. See Judith Butler, El género en disputa. El feminismo y la subversión de la identidad. Barcelona: Paidós, 2007, p. 17.

[25] See Marinela Miano Borusso and Águeda Gómez Suárez, "Dimensiones simbólicas sobre el sistema sexo/género entre los indígenas zapotecas del Istmo de Tehuantepec (México)", Gazeta de Antropología, No. 22, 2006, p. 12-13.

[26] Veronika Bennholdt-Thomsen, Juchitán, la ciudad de las mujeres, p. 24-25.

[27] Michel Foucault, "El cogito impensado," in Las palabras y las cosas. México: Fondo de Cultura Económica, 1968, p. 313319.

[28] For Foucault, devices form part of the "general strategy of power" and allow the State to control people's lives. See Michel Foucault, "Clase del 11 de enero de 1978" in Seguridad, Territorio, Población. Curso en el Collège de France (1977-1978). Buenos Aires: Fondo de Cultura Económica, 2006, p. 15-44.

[29] See Iohann Baptist Metz, Memoria passionis, una evocación provocadora en una sociedad pluralista. In collaboration with Johann Reikerstorfer. Santander: Sal Terrae, 2007; Johann Baptist Metz, Por una cultura de la memoria. Barcelona: Anthropos, 1999.

[30] See Gustavo Gutiérrez, Teología de la Liberación. Perspectivas. Salamanca, CEP, 1972.

[31] Boaventura de Sousa Santos, Para descolonizar Occidente, más allá del pensamiento abismal. Buenos Aires: CLACSOPrometeo Libros, 2010, and Una epistemología del sur: la reinvención del conocimiento y la emancipación social. México: Siglo XXI-CLACSO, 2011.

[32] Achile Mbembe, Necropolítica. Seguido de Sobre el gobierno privado indirecto. Spain: Melusina, 2011.

[33] See the chapter "Imaginando el cambio de mundo" in Carlos Mendoza-Álvarez, Deus ineffabilis. Una teología posmoderna de la revelación del fin de los tiempos. Barcelona/México: Herder/Universidad Iberoamericana, 2015, p. 392-394.

[34] Sayak Valencia, Capitalismo gore. Spain: Melusina, 2010.

[35] See Raúl Zibechi, Latiendo Resistencia. Mundos nuevos y guerras de despojo. México: El Rebozo, 2015.

[36] See María Stella Rodríguez Arenas, La resiliencia como vivencia del Reino de Dios, 39.

[37] Carlos Mendoza-Álvarez, Deus ineffabilis. Una teología posmoderna de la revelación del fin de los tiempos. Barcelona/México: Herder/Universidad Iberoamericana, 2015. 